\title{
FEASIBILITY OF INULIN HYDROLYZATES USAGE IN THE PRODUCTION OF HEALTH IMPROVING PRODUCTS
}

\author{
K. V. DMYTRASH \\ National Aviation University, Kyiv
}

The structure of biologically active compounds of Cichorium intybus is studied. The influence of chicory components on human health is defined. The benefits of fructose syrups using over glucose are showed. The fields of fructose syrup usage as alternative sugar products are revealed.

Key words: Cichorium intybus, inulin, hydrolysis, high fructose syrup.

The problem of finding and developing ways to reduce the negative impact of environmental pollution on human health is global. Factor in the deterioration of their health is also poor diet, especially consumption of refined products, which is mass coming from abroad. Health products of many foreign companies do not correspond advertised qualities, also them have too high prices and that results in low competitive ability of domestic producers. The particular importance has the problem of the development of domestic food health care appointment on the basis of local plant material, including inulin containing. Important area of development is the industrial Cichorium intybus recycling, which is rich in many valuable bioactive compounds with protective and prebiotic actions [1].

An improved method for high-fructose syrups production is based on the obtaining of syrups by partial inulin hydrolysis from chicory in neutral conditions without chemical addings that do not require additional costs for cleaning.

The use of chicory in various areas as a source of biologically active substances requires investigation of raw materials of Ukraine to produce fructose syrups on an industrial scale. 
In the last years active research is conducted in identifying the newest method of tools development that serve as a relevant sweetener products and usage relatively cheap domestic raw materials. Revealed the following sources of inulin as artichoke, molasses, sugar beets, elecampane [2, 7]. However, there isn't sufficiently consider the Cichorium intybus using possibility as the main raw material.

There are great practical interest is the possibility of inulin containing plants in the food and pharmaceutical industries.

The main aim of this article is to determine the scope of chicory components and also to make the research of chicory components influence on the human health, including inulin.

Chicory (Cichorium intybus) - genus of herbaceous plants of the family Asteraceae.

In the chicory roots there is a large number of carbohydrates, such as bitter glycoside intibin, lactucyn, triterpene, coumarinic glycoside chicoryin, ascorbic acid, $\mathrm{B}$ vitamins and others. However, the main one is inulin.

Inulin $\left(\mathrm{C}_{6} \mathrm{H}_{10} \mathrm{O}_{5}\right)_{\mathrm{n}}-$ widespread in nature reserve polysaccharide consisting mainly of D-fructoseresidues connected by 1,2-glycoside bonds. Inulin molecule contains a small amount of glucose residual [4]. Inulin structural formula is shown in Figure 1.

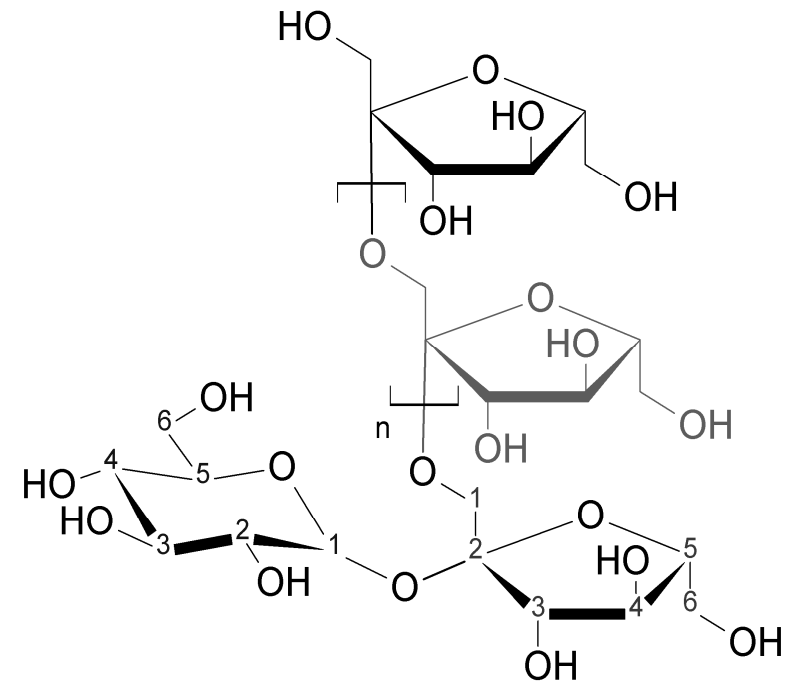

Figure 1. Structural formula of inulin 
Inulin is a white crystalline powder, with sweet taste that is easily soluble in hot water. Molecular weight is $5000-6000 \mathrm{~g} / \mathrm{mol}$.

The high fructose syrups can be produced from inulin directly as an alternative of sugar products.

Fructose has some specific properties: high sweetness (in 1.5-1.8 times) in comparison with sucrose, the ability to enhance the taste and smell of food, the ability to prevent confectionery harden. Such properties of fructose syrups can contribute to successful replacement of sucrose in soft drinks, canning, confectionery and other industries where traditionally used sugar [6].

Inulin is common in nature reserve polysaccharide obtained from chicory roots. It not only stimulates the growth of bifidobacteria, but also helps to excrete the various endo- and exotoxins. Inulin is easy to hydrolyze. The products of partial and total hydrolysis of inulin are inulibiozy and fructose. These hydrolysates can be used to extract fructose-oligosaccharides syrups that contain most of biologically active constituents of chicory and satisfy the needs of the food industry to create products of health-care setting.

The technology for obtaining fructose-oligosaccharide mixture allows obtaining of fructose-syrup by partial hydrolysis of chicory inulin in neutral conditions without adding chemicals that do not require additional cleaning costs [7]. Enzyme treatment of chicory roots containing inulin. The result is thickened and sterilized fructose solution. These syrups contain about $80 \%$ fructose and $2 \%$ glucose [3]. They are a thick liquid from light to dark brown in color, pleasant sweet taste with a characteristic odor. These syrups have a positive effect on cholesterol and uric acid content of the human body and stabilize the amount of glucose in the blood. They are easily digested and can be used as a type of soluble dietary fiber lowering calories.

In the pharmaceutical industry fructose syrups can be under used following diseases: pneumonia, diseases of gastro-intestinal tract, liver cirrhosis, jaundice, spleen tumors, toothache, gastroenteritis, colitis, kidney disease, scurvy, anemia.

The roots of chicory can be used as substitute of coffee and other beverages due to their aromatic properties and taste [1]. 
Food sweeteners based on fructose syrups are needed in the production of dietary products and baby food. In addition, fructose absorption by the body occurs without insulin, making it necessary for patients with diabetes, which in Ukraine, according to the Ministry of Health, there are about one million people.

The feasibility of using fructose syrups in health confirmed for world science and practice. Particularly in the U.S.A. and Europe resulting concatenated efforts of technologists, nurses and financiers manufactured over 30 kinds of sugary products, including the fate of fructose syrup is $18-22 \%$ and growing. The growth of new products containing fructose syrups shown in Figures 2 and 3.

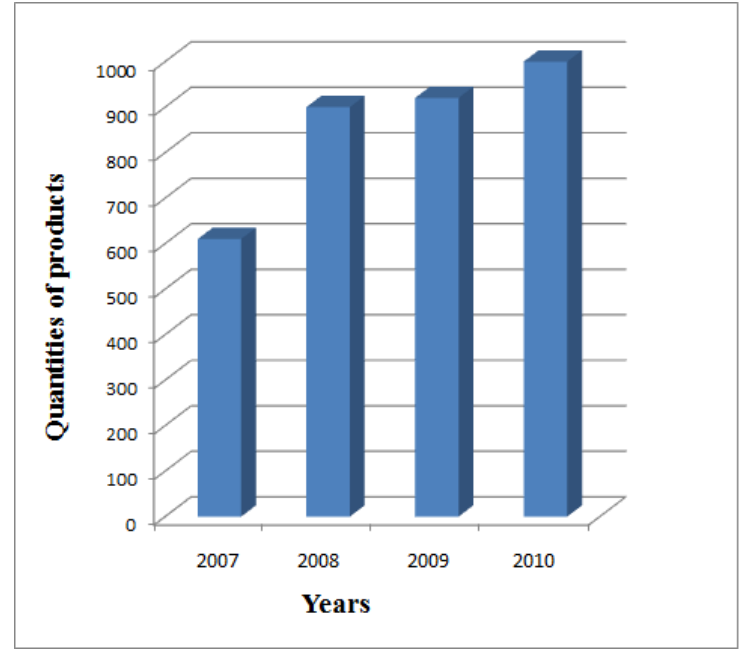

Figure 2. Quantity growth of new products in the USA and Europe

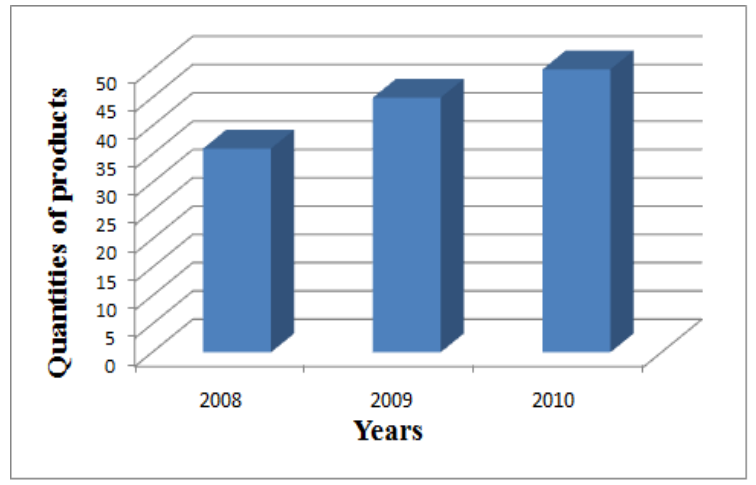

Figure 3. Consumption growth dynamics in Russia

The feasibility of raw material using is defined, as a rule, by the specific agricultural sector of each country.

In this regard, we consider a promising direction of development of food production fructose syrup based on chicory - domestic, relatively cheap, available in sufficient quantities raw materials.

In natural conditions chicory spread throughout Ukraine as a weed plant. It can be found along roads, in clearings and other uncultivated areas. Chicory is massively grown as cultivated plant for a long term. In 1918 in Russia chicory occupied an area of 4000 hectares, in 1947 in the Soviet Union - 20,000 hectares, accounting for half 
of its acreage in Europe. Currently chicory is grown only in Ukraine specialized farms and amateurs [5].

Fructose and high fructose syrup are not made for the needs on an industrial scale in Ukraine and the former Soviet Union, it is imported from abroad. There is a problem: having enough of its own raw materials, Ukraine buys the finished product in countries where raw material costs significantly more.

\section{CONCLUSION}

Chicory shows protective, prebiotic and antioxidant properties.

Inulin is reserve polysaccharide rich in fructose that was the most investigated component in chicory.

The high fructose syrup derived from inulin contains most biologically active constituents of chicory. They can largely meet the needs of the food industry in production of health care products based on domestic raw materials.

The feasibility and socio-economic efficiency of production technology of fructose syrups confirmed international practice, due to the needs of domestic consumers and the presence of abundant domestic resource base.

\section{REFERENCES}

1. Simmonds P. L. Coffee and chicory, their culture / Peter Lund Simmonds. UK: Spon, 2000. - 245 p.

2. Charalampopoulos D. Prebiotics and Probiotics Science and Technology / R. A. Rastall. - UK: Springer, 2009. - 622 p.

3. Попова I. В. Обгрунтування ефективних способів гідролізу інуліну цикорію та використання гідролізатів в харчових технологіях : автореф. дис. на здобуття наук ступеня канд. техн. наук : спец. 05.18.05 «Технологія цукристих речовин та продуктів бродіння» / І. В. Попова. - Київ, 2007. - 24 с.

4. Остапець М. Г. Практикум з біохімії / Остапець М. Г., Романська Н. М. - Київ: Вища школа, 1974. - 251с. 
5. Лікарські рослини: Енциклопедичний довідник / За ред. А.М. Гродзінського. - К.: "Українська енциклопедія", 1992. - 544 с.

6. Лавренов В. К. Энциклопедия лекарственных растений народной медицины: підруч. [для студ. вищ. навч. закл.] / В. К. Лавренов, Г. В. Лавренова. - СПб: Нева, 2003. - 352 с.

7. Пат. 14753 України, МПК 7 C 02 F1/28, C 02 F1/36. Спосіб одержання фруктозо-олігосахаридних сумішей / Попова I. В., Лезенко Г. О., Українець А. І., Хомічак Л. М., Дашковський Ю. О., Василів В. П., Маринін А. І.; власник патенту Національний університет харчових технологій. - № 200512662; заявл. 27.12.2005; опубл. 15.05.2006, Бюл. №5.

\title{
ДОЦІЛЬНІСТЬ ВИКОРИСТАННЯ ГІДРОЛІЗАТІВ ІНУЛІНУ У ВИРОБНИЦТВІ ПРОДУКЦЇ̈ ОЗДОРОВЧОГО ХАРАКТЕРУ
}

\author{
Х. В. ДМИТРАШ \\ Наџіональний авіаџійний університет, м. Київ
}

Досліджено склад біологічно активних речовин цикорію. Виявлено вплив компонентів цикорію на організм людини. Наведено переваги використання фруктозних сиропів над глюкозою. Визначено сфери використання фруктозних сиропів як альтернативи иукропродукта.

Ключові слова: Cichorium intybus, інулін, гідроліз, фруктозний сироп. 


\title{
ЦЕЛЕСООБРАЗНОСТЬ ИСПОЛЬЗОВАНИЯ ГИДРОЛИЗАТА ИНУЛИНА В ПРОИЗВОДСТВЕ ПРОДУКЦИИ ОЗДОРОВИТЕЛЬНОГО ХАРАКТЕРА
}

\author{
Х. В. ДМИТРАШ \\ Наџиональный авиаџионный университет, г. Киев
}

Исследован состав биологически активных веществ иикория. Выявлено влияние компонентов иикория на организм человека. Приведены преимущества использования фруктозного сиропа над глюкозой. Определены сферы использования фруктозного сиропа как альтернативы сахаропродуктам.

Ключевые слова: Cichorium intybus, инулин, гидролиз, фруктозный сироп. 